A heavy train of dining and sleeping carriages, with two engines, conveying one of the crowned heads of Europe and suite, arrived at the exit of Pracchia Tunnel with both enginemen and both firemen insensible; and in other cases passengers have been seriously affected.

Owing to the height of the mountain no shafts are available; but Signor Saccardo places a ventilating fan near the mouth of the tunnel, and blows air into it through the annular space which exists between the arch of the tunnel and the gauge of maximum construction (Fig. 6). The results are renarkable; the volumes of air thrown into the tunnel per minute being as follows :-

$$
\begin{array}{rrrrrr}
\text { Direct from the fan } & \ldots & \ldots & \ldots & \ldots & \begin{array}{r}
\text { cub. ft. } \\
16 \mathrm{r}, 860
\end{array} \\
\text { Induced draught through open tunnel mouth } & \begin{array}{r}
48,140 \\
\text { Total }
\end{array} \quad \ldots & \ldots & \ldots & 210,000
\end{array}
$$

Or roo cubic metres per second.

The temperature of the tunnel air before the fan was started was $107^{\circ} \mathrm{F}$., with 97 per cent. of moisture, whereas, after the fan had been running a few minutes the temperature was $8 \mathrm{I}^{\circ} \mathrm{F}$. or a lowering of $26^{\circ} \mathrm{F}$., and the tunnel was cool and free from smoke and vapour.
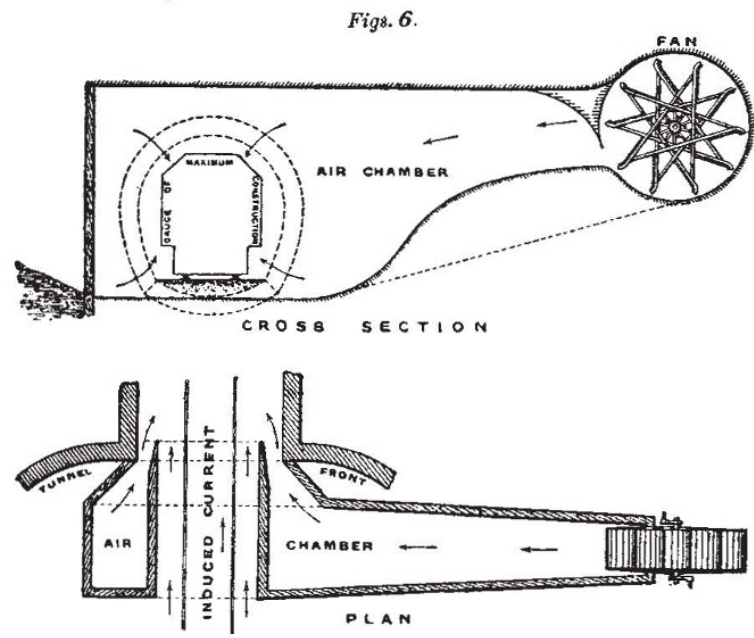

The saccardo Sygtem of Ventilating Tunnels.

One can travel through with both windows open and feel no inconvenience, the only remark of the brakesman riding on the top of the waggons and carriages being that he finds it almost too cold.

This application is without doubt the solution of the difficul problem of tunnel ventilation under high mountains, and elsewhere where shafts are not available, and where electric traction is not applicable.

This system has within the last twelve months been brought into operation on the St. Gothard, with the most satisfactory results. Careful experiments are being made, but there is no doubt that the problem has been solved.

In addition to these tunnels, the Saccardo system has been applied to the Giovi Tunnel near Genoa-3300 metres in length-and is being installed on the Giovi Tunnel on the Genoa-Ronco Railway, 8303 metres in length, besides on some seven other tunnels in Italy; and plans are being prepared for the Mont Cenis.

\section{The Simplon Tunnel.}

This tunnel is now in rapid course of construction, the total length of gallery driven up to the end of April being as follows :- -

$$
\begin{array}{lllll}
\text { On the north or Brigue side of the Alps } & \ldots & \begin{array}{l}
\text { yards } \\
\text { Ond }
\end{array} \\
\text { On the south or Iselle } \ldots & \ldots & \ldots & \ldots & 2350
\end{array}
$$

Or over three miles in little more than eighteen months, in cluding the necessarily slow progress at the commencement.

The total distance between the two portals will be 21,564 yards, or 12.26 miles. A gallery of direction has been driven at both ends until the actual tunnels are reached, so as to form NO. I603, VOL. 62 ] a directly straight line for the accurate alignment of the work from end to end.

This great undertaking will consist of two single-line tunnels running parallel one to the other, at a distance apart from centre to centre of 55 feet 9 inches; and one of the chief features is the much lower altitude of the rails above sea-level than any of the other Alpine tunnels. This altitude is at its highest point 2314 feet, being 1474 feet lower level than that of the St. Gothard, 1934 feet lower than that of the Mont Cenis, and 1986 feet than that of the Ariberg. This is a matter of great importance in the question of haulage of all the traffic.

The tunnel enters the mountain at the present level of the railway at Brigue, so that no costly approaches are requisite on this side.

Admirable arrangements have been made for the welfare of the men, to avoid the heavy death-rate which occurred on the St. Gothard, and it may be interesting to state what some of these are. For every cubic foot of air sent into the latter tunnel, fifty times as much will be delivered into the Simplon. Special arrangements are made for cooling the air by means of fine jets of water and spray.

The men on emerging from their work, wet through and fatigued, are not allowed to go from the warm headings into the cold Alpine air outside, but pass into a large building which is suitably warmed, and where they change their mining clothes and are provided with hot and cold douche baths. They put on warm dry clothes, and can obtain excellent food at a moderate cost before returning to their homes. Their wet and dirty mining clothes are taken charge of by appointed custodians, who dry and clean them ready for the morrow's work. These and other precautions are expected to reduce the death-rate to a very great extent.

With a view to the rapid advancement of the work, the late M. Brandt, whose death is greatly to be deplored, devised after his long experience on the St. Gothard his now well-known drill. As details of this have been published, and as they would he too technical for this evening's discourse, it will only be necessary to refer to them briefly. This drill is non-percussive, nor is it armed with diamond. It is a rotatory drill 3 inches in diameter with a pressure on the cutting points of ro tons moving at slow speed, but capable of being acclerated at pleasure, and of being rapidly withdrawn.

The progress of each of the two faces during the month of April last has averaged $I 7$ feet $3 \frac{1}{\frac{1}{2}}$ inches per day, and is a remarkable corroboration of the speed estimated by the engineers four years ago. The estimate was as follows:-

ist year, the daily progress at each face would be $\ldots \quad 8.85$ feet and ," $, \quad ", \quad, \quad, \quad \ldots 17 \cdot 22$, 3rd ", ", ", $\quad$ ", $\quad, ", \quad \ldots .17 .22$, 4th , $\quad, \quad, \quad,, \quad,, \quad \ldots 2$ I 32,

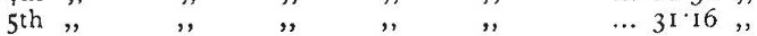

The work is now in its second year, so that the estimated speed is being exceeded. In other words, the tunnel is being driven through granite at a higher speed than is attained in London clay.

It was at one time intended to sink a 20 -inch bore-hole from the village of Berisal to the tunnel, a depth of some 2400 feet, for the purpose of delivering water at high-pressure for the works. This may still be done, but the meandering of the tool might result in the awkward dilemma of having to search for it, in solid rock, below ground.

The probable cost of the work now in hand will be about $2,000,000 \%$., and the time occupied in completing the tunnel ready for traffic is estimated to be $5 \frac{1}{2}$ years, a penalty or a bonus, as the case may be, for delay or acceleration being fixed at $200 l$. a day.

\section{UNIVERSIT Y AND EDUCATIONAL} INTELLIGENCE.

OXFORD. - The following is the text of the speech with which Prof. J. Mark Baldwin, professor of psychology in Princeton University, was presented for the degree of D.Sc. honoris causa. This is the first time the degree has been conferred in Oxford, it having been created only quite recently. The speech was written by Mr. A. C. Clark, of Queen's College, and Prof. Baldwin was presented by Prof. E. B. Elliot, F.R.S., in the absence of Prof. Love, F.R.S., who would in the ordinary 
course have officiated, being the occupant of the oldest scientific chair in the University :

Adest Jacobus Marcus Baldwin, Academiae de Princeton Graduatus, vir Psychologiae peritissimus. Cujus laudes ut brevissinie complectar, primo Psychologiae Professor in Academia de Toronto creatus Psychologiae Experimentalis laboratorium, quod solum adhuc in Academiis Britannicis exstat, instituit, mox ad suam almam matrem reversus in Academia de Princeton Psychologiae Professor factus est. Libri etiam luculentissimi auctor est de ortu et incremento intellegentiae cum in infantibus tum in genere hominum universo, quem summa laude a viris doctis ubique ornatum Academia Havniensis numismate aureo donavit: idem ephemeridis praestantissimae apud Americanos res psychologicas tractantis diu editor, nunc grande Philosophiae et Psychologiae Abecedarium sub prelo nostro excudendum curat. Quo in labore doctissimi cujusque in hoc genere scriptoris opera utitur cum in America tum in Europa, quo in numero Praelector noster Wildianus dux est et fere signifer. Valde, nisi fallor, Academiae nostrae auram redolebit hoc volumen tot Oxoniensium sive sub nostro caelo, sive sub externo degentium, opera diligentia doctrina exquisita ornatum.

Quod vero primus Scientiae Doctor in Academia nostra creatus tantam in Psychologia laudem adeptus sit, felicissime profecto accidit, cum adhuc frigere apud nos hujus doctrinae studium externis videatur. Utinam hunc talem virum plurimi ejusdem laureae avidi longo ordine secuturi sint.

Illam vero insignem benevolentiam praetermittere non possum Academiae de Princeton, quae plurimos, qui in hac nostra Academia laude summa floreant ac floruerint, gradibus honoris causa conferendis libentissime auxerit. Cujus liberalitatis non immemor maximo cum gaudio ego hunc virum doctissimum, Academiae suae vivum exemplar, vobis ornandum trado.

The speech delivered by Prof. Love on the occasion of the presentation of Prof. C. F. Chandler, of Columbia College, for the degree of D.Sc. honoris causa, was as follows:-

Adest Carolus Fredericus Chandler, chemiæ professor apud Americanos, cuius fama extra fines patria suæ iam dudum pervagata est. Hic apud suos litteris humanioribus primo imbutus, dein chemiæe deditus doctrinæe amplioris appetens ad Germanorum fontes accessit. Ibi doctissimi cuiusque viri, cum in Berolinensi Academia, tum in Gottingensi discipulus, Philosophiæ Doctor et Magister Artium apud Gottingenses creatus est. Ex hoc curriculo ad solum suum reversus in Academia de Schenectady primo vicarius erat Professoris optimi, Caroli Joy, dein hoc summo viro ad Academiam de Columbia avocato, ipse Professor factus septem annos de omni chemiæ genere, de agris letificandis, de metallorum ratione, de geologia magnum discipulorum gregem praeclare docebat. Ita laudem insignem adeptus ipse Columbiam arcessitus, ubi scholæ metallorum novo exemplo instituendæ imprimis auctor erat, tres et triginta annos in omni rerum administratione florebat. Per hoc grande mortalis ævi spatium omne genus chemize felicissime tractavit idem rude iam donatus a laboribus officiosis nondum recessit sed iuniorum studia adhuc informat. Neque hoc loco silendum arbitror quod huius precibus commoti fratres Havermeyeri, Novi Eboraci cives ornatissimi, aulam pulcherrimam, chemiæ sedem, rdificaverunt: Musei etiam rebus omnibus, quxe ad chemiam pertinent, refertissimi ipse auctor est et conditor. Sex et viginti abhinc annos magna chemicorum frequentia ad Doctoris Priestly sepulchrum confluente, ut chemiæ inventorem rite salutarent et post centesimum iam annum scientiæ suæ natalem diem celebrarent, ipse conventus Præses erat: Societas autem chemicorum Americanorum, quæ ex illo coetu orta est, hunc bis Præsidem sæpe vice-Præsidem et curatorem habuit. Sodalicii etiam chemicorum, qui Novi Eboraci degunt, Præses est: hortorum etiam publicorum peritissimus Curator. Idem civitatis suxe personam gerens maximo medicorum conventui Havniæ interfuit, qui ab omni terrarum orbe missi de valetudine civium conservandá quærerent.

Dies mehercule me deficeret si doctissimi viri tot labores enumerare conarer. Illum consulunt populares sui de porcorum fibra unaquaque in quæstum convertenda, de silvis rei navalis causa conservandis, de veneno si quod in vino vel in cervisia delitescat detrahendo, de argentariorum chartulis imperviis aquæ et madori reddendis, de oleo e vivis fontibus scaturiente purgando, de plateis igneo vapore noctu illuminandis, de mercibus linteis candore eximio nivem superantibus, de omni re quæ ad utilitates, oblectamenta, licrum denique civium pertinet.

Ut omittam honores quos Academia Gottingensis iuveni dedit,
Doctor Medicinæ ab Academia Novi Eboraci, Litterarum etiam Doctor ab Academia sua Columbiensi factus est : neque solum domi clarus est, sed ubicunque terrarum viri docti, chemix dediti, inveniuntur, hunc sodaliciis et societatibus suis Jibentissime adsoiverunt. Restat ut Academia nostra hoc summo viro in gremium suum accepto suas laudes augeat.

AT a meeting of the Council of the Birmingham University, held on Tuesday, the following letter, received from Lord Calthorpe by Mr. Chamberlain, was read:--"Dear Mr. Chamberlain,-My son and myself beg to offer to the University of Birmingham about twenty-five acres of land on the Bournebrook side of the Edgbaston estate as a site for the new scientific department of teaching and research which it is proposed to establish. There will of necessity be certain conditions, but these will occasion no difficulty. - Yours very truly, CALTHORPE." It was proposed by the Vice-Chancellor, seconded by Sir James Smith, and unanimously resolved :- "That this Council desires to express to Lord Calthorpe and to the Hon. Walter Calthorpe its high appreciation of their generosity in offering to present twenty-five acres of land to the University of Birmingham as a site for the new scientific department. In gratefully accepting the offer, the Council recognises, not only the value of the gift, but the suitability of the site, which enables it to establish the new department in closer proximity to the centre of the city than would have been possible under any other circumstances."

THE Reports and Prospectuses of Technical Schools, which come under our notice from time to time, show unmistakably that increased provision is being made for practical work in science, and that teachers who have had the advantage of instruction in well-equipped laboratories are in charge of the work. The Municipal Science, Art, and Technical Schools of Plymouth is a case in point. These schools were erected by public subscription as a memorial of the Queen's Jubilee, and on their completion were handed over by the Jubilee Memorial Committee to the town. In the day school department the work is that of the Advanced Section of a "School of Science," that is to say, of a secondary school giving instruction in mathematics, mechanics, physical science, English subjects, French and drawing. There is a laboratory for practice in both chemistry and physics, and for manual instruction in woodwork. Both day and evening classes are held in many science subjects, and pupils whose elementary education is completed may take a two years' course of training in such subjects as will best fit them to become chemists, architects, civil, mechanical, or electrical engineers, or to engage in industrial work of any kind. The increase of institutions of this kind will be the salvation of our national welfare.

From the Northampton Institute, one of the youngest of the London Polytechnics, we have received a prospectus of courses in mechanical engineering, electrical engineering, and horological engineering which have just been introduced. The syllabuses of the courses are admirable, and, with the notes upon the objects and character of the work, they indicate that Dr. R. M. Walmsley, the principal, believes in the value of scientific instruction. Students who desire to take up these engineering courses must first show that they are capable of benefiting from it by passing an entrance examination. English and elementary mathematics are obligatory subjects, and we are glad to see that it is not proposed to make the latter a test of ability to perform mathematical gymnastics. The following extract from the prospectus is worth quoting:- "In "Elementary Mathematics" the examination will aim at ascertaining the candidate's familiarity with simple arithmetical, algebraical and geometrical methods and their application so the solution of ordinary common-sense problems. In arithmetic this will include the use of decimals and abbreviated methods of calculation, with the usual problems of mensuration, including the volumes and surfaces of cylinders, spheres and right cones. In algebra the usual course as far as simple simultaneous equations will be in. cluded, but the more academic parts of the subject will not be required. The geometry will include the subjects treated in the firsi two books of Euclid, with some exercises in the accurate drawing of geometrical figures." The Institute has numerous laboratories and workshops for practical work in mechanics, engineering, metal and woodwork, electrical engineering, physics, electro-chemistry, metallurgy, and instrument making. The attention given to horological theory and mechanism, and

NO. I6O3. VOI. 62 ] 
horological technology, is a noteworthy characteristic. Th courses of work in this as well as the other subjects show that sound instruction in the principles and practice of the chief branches of engineering can be obtained at the Institute.

\section{SCIENTIFIC SERIALS}

American Journal of Science, July.-Energy of kathode rays, by W. G. Cady. This is a translation of a paper already published in the Annaten der Physik.-Volcanic rocks from Temisconata Lake, Quebec, by H. E. Gregory. The volcanic rocks consist of fine tuff and coarse amygdaloidal conglomerate or breccia. They are interbedded with Niagara sediments, and this helps to determine the time when widespread volcanic activity gave rise to the numerous small areas of tuffs and lavas in the Maine-Quebec region.--Interpretation of mineral analyses, and a criticism of recent articles on the constitution of tourmaline, by S. L. Penfield. It is safe to assume that the close approximation of atomic ratio to whole numbers constitutes the strongest argument that can be advanced in support of the excellence of an analysis and to correctness of the derived formula. The author criticises the formulæ proposed by Clarke and Tschermak, and maintains that it is definitely proved that the empirical formula of the tourmaline acid is $\mathrm{H}_{20} \mathrm{~B}_{2} \mathrm{Si}_{4} \mathrm{O}_{21}$. Carboniferous boulders from India, by B. K. Emerson. The author describes and illustrates some striated carboniferous boulders which remove the doubt as to the former existence of a carboniferous glacial period. - The statement of rock analyses, by H. S. Washington. The author proposes a regular system of stating the results of the chemical analysis of rocks. The oxides are to be enumerated in the following succession: $\mathrm{SiO}_{2}$, $\mathrm{Al}_{2} \mathrm{O}_{3}, \mathrm{Fe}_{2} \mathrm{O}, \mathrm{FeO}, \mathrm{MgO}, \mathrm{CaO}, \mathrm{Na}_{2} \mathrm{O}, \mathrm{K}_{2} \mathrm{O}, \mathrm{H}_{2} \mathrm{O}, \mathrm{CO}_{2}$, and then the rarer oxides, also in definite succession. This will enable the geologist to classify the rocks in a purely chemical system and to pick them out at a glance. They can be advantageously entered upon a card catalogue.-A string alternator, by K. Honda and S. Shimizu. The authors describe a modification of Pupin's string interrupter by means of which a continuous battery current can be converted into an alternating current the frequency of which can be readily varied from 30 to rooo per second.--Action of light on magnetism, by J. H. Hart. The author failed to obtain the demagnetisation of iron by light acting magnetically like an alternating current, until he adopted the expedient of depositing very fine iron films on glass. $\mathrm{He}$ then noticed a small but distinct difference in the magnetic state of the iron according to the plane of polarisation of the incident light.

Bollettino della Societì Sismolorica Italiana, vol. vi. I9001901, N. I.-Rules and list of fellows (forty-three national and thirteen foreign).--Vesuvian notices (year I 899), by G. Mercalli. A monthly review of the condition of Vesuvius, with sections on the form and state of the crater, the end of the eruptive phase of $1895-1899$, the lavic cupola of $1895-1899$, the supposed endogenous elevation of the lavic cupola, and the fumaroles of the lavic cupola and fracture.-On the nature of seismic vibrations, by M. P. Rudski (in French). The author contends that superficial, and probably deep-seated, rocks are not isotropic media, and that earthquake waves consist of vibrations which are not entirely longitudinal or entirely transversal. - Notices of earthquakes recorded in Italy (January $\mathrm{I}$ to March I4, I896), by $\mathrm{A}$. Cancani, the most important being the Mexican earthquakes of January 14 and 25, the Greek earthquake of January 22, and distant earthquakes on January 6, 22, and March 7 .

\section{SOCIETIES AND ACADEMIES.}

\section{LONDON.}

Royal Society, May 17.- "The Circulation of the Surface Waters of the North Atlantic Ocean." By H. N. Dickson, B.Sc. Communicated by Sir John Murray, K.C.B., F.R.S.

In this paper an attempt is made to investigate the normal circulation of the surface waters of the Atlantic Ocean north of $40^{\circ} \mathrm{N}$. lat, and its changes, by means of a series of synoptic charts showing the distribution of temperature and salinity over the area for each month of the two years 1896 and 1897 .
The principal conclusions arrived at with reference to the circulation may be summed up as follows :-

(I) The surface waters along the whole of the eastern seaboard of North America north of (about) lat. $30^{\circ} \mathrm{N}$., consisting partly of water brought from the equatorial currents by the Gulf Stream, and partly of water brought down by the Labrador current, are drifted eastward across the Atlantic towards southwestern Europe, and banked up against the land outside the continental shelf. This continues all the year round, but it is strongest in summer, when the Atlantic anti-cyclone attains its greatest size and intensity; and the proportion of Gulf Stream water is greatest at that season.

(2) The drifts in the northern part of the Atlantic area are under the control of the cyclones crossing it. The circulation set up accordingly reaches its maximum intensity in winter, and almost dies out in summer. In winter the drifts tend to the south eastward from the mouth of Davis Strait, eastward in midAtlantic, and north-eastward in the eastern region. In spring and autumn the movement is more easterly over the whole distance, and a larger quantity of water from the Labrador stream is therefore carried eastward.

(3) The water banked up in the manner described in (I) escapes partly downwards, partly southwards, and partly northwards. It occupies the whole of the eastern basin of the North Atlantic, and to the north it' extends westward to Davis Strait, being confined below 300 fathoms depth by the ridges connecting Europe, the Faerues, Iceland, and Greenland. Above that level it escapes northward by a strong current through the Faeroe-Shetland Channel and between Faeroe and Iceland, and by the two branches of the Irminger stream, one west of Iceland the other west of Greenland.

(As it seems desirable that this northerly current should have a distinctive name, it might be well to call it the European stream, and its branches the Norwegian, Irminger, and Greenland streams respectively.)

The strength and volume of the European stream is liable to considerable variation, according to the form and position of the Atlantic anti-cyclone, which causes the amount of banked up water, and the proportions escaping northward and southward, to vary. It is also modified by the strength and direction of the surface drifts in its course. It is, however, always strongest in summer.

(4) The Norwegian stream is by far the largest branch of the European, and it traverses the Norwegian Sea and enters the Arctic Ocean. The warm water thus sent northward melts enormous quantities of ice, and the fresh water derived from the ice moves southward in autumn, chiefly in a wide surface current, between Iceland and Jan Mayen, which may entirely cover other parts of the Norwegian stream. Part of the surface water also comes southward through the Denmark Strait, but the amount is nuch smaller, probably chiefly because the melting of the ice is slower, and the channel is longer blocked.

The Greenland branch of the European current also causes melting of ice in Davis Strait, but the warm winds from the American continent and the water received from the land are probably more effective in increasing the volume of the Labrador current.

(5) The water from the melted ice is spread over the surface of the North Atlantic during late autumn and winter by the increasing drift circulation, and it is gradually absorbed by mixing with the underlying water.

(6) The circulation described is liable to extensive irregular variatious, corresponding to variations in the atmospheric circulation.

May 31.- "Influence of the Temperature of Liquid Hydrogren on Bacteria." By Allan Macfadyen, M.D., and Sydney Rowland, M.A. Communicated by Lord Lister, P.R.S.

In a previous communication we have shown that the temperature of liquid air has no appreciable effect upon the vitality of micro-organisms, even when they were exposed to this temperature for one week (about $-190^{\circ}$ C.). (Roy. Soc. Proc., February I ; ibid., April 5.)

We have now been able to execute preliminary experiments projected in our last paper as to the effect of a temperature as low as that of liquid hydrogen on bacterial life. As the approximate temperature of the air may be taken as $300^{\circ}$ absolute, and liquid air as $80^{\circ}$ absolute, hydrogen as $21^{\circ}$ absolute, the ratio of these temperatures roughly is respectively as $15: 4: 1$. In other words, then, the temperature of liquid

NO. 1603 , VOL. 62] 